In cooperation with

Suffolk County Water Authority

\title{
Occurrence of Arsenic in Ground Water of Suffolk County, New York, 1997-2002
}

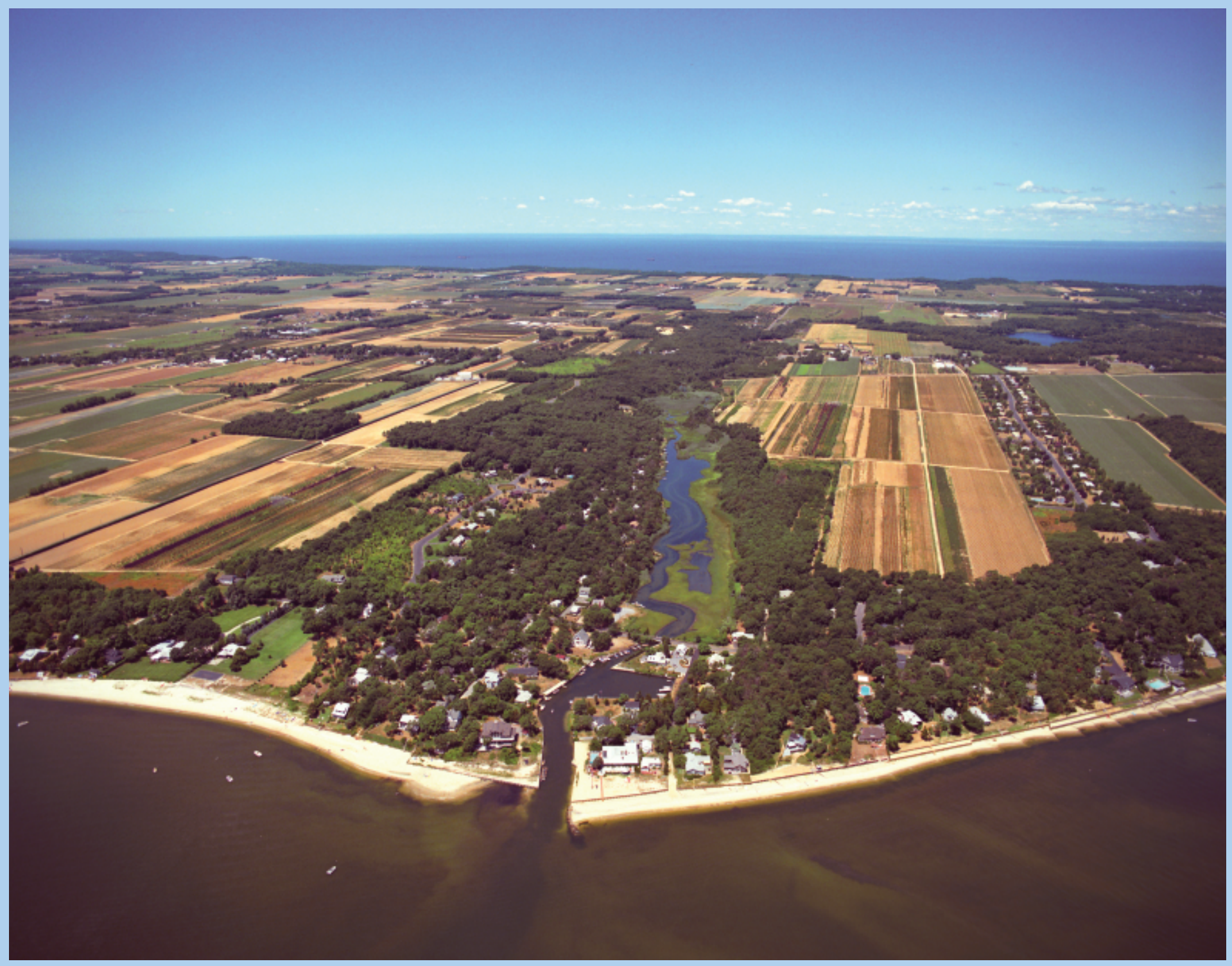

Water-Resources Investigations Report 03-4315

U.S. Department of the Interior

U.S. Geological Survey 
Cover. Brushs Creek, Laurel, New York, (C) Joseph R. Melanson of skypic.com 


\section{Occurrence of Arsenic in Ground Water of Suffolk County, New York, 1997-2002}

By Richard A. Cartwright

Water-Resources Investigations Report 03-4315 


\title{
U.S. Department of the Interior \\ Gale A. Norton, Secretary \\ U.S. Geological Survey \\ Charles G. Groat, Director
}

\author{
U.S. Geological Survey, Reston, Virginia: 2004 \\ For additional information about this report write to: \\ U.S. Geological Survey \\ 2045 Route 112, Bldg. 4 \\ Coram, NY 11727 \\ Email: askny@usgs.gov \\ World Wide Web: http://ny.usgs.gov/ \\ For sale by U.S. Geological Survey, Information Services \\ Box 25286, Denver Federal Center \\ Denver, CO 80225 \\ For more information about the USGS and its products: \\ Telephone: 1-888-ASK-USGS \\ World Wide Web: http://www.usgs.gov/
}

\footnotetext{
Any use of trade, product, or firm names in this publication is for descriptive purposes only and does not imply endorsement by the U.S. Government.

Although this report is in the public domain, permission must be secured from the individual copyright owners to reproduce any copyrighted materials contained within this report.
} 


\section{Contents}

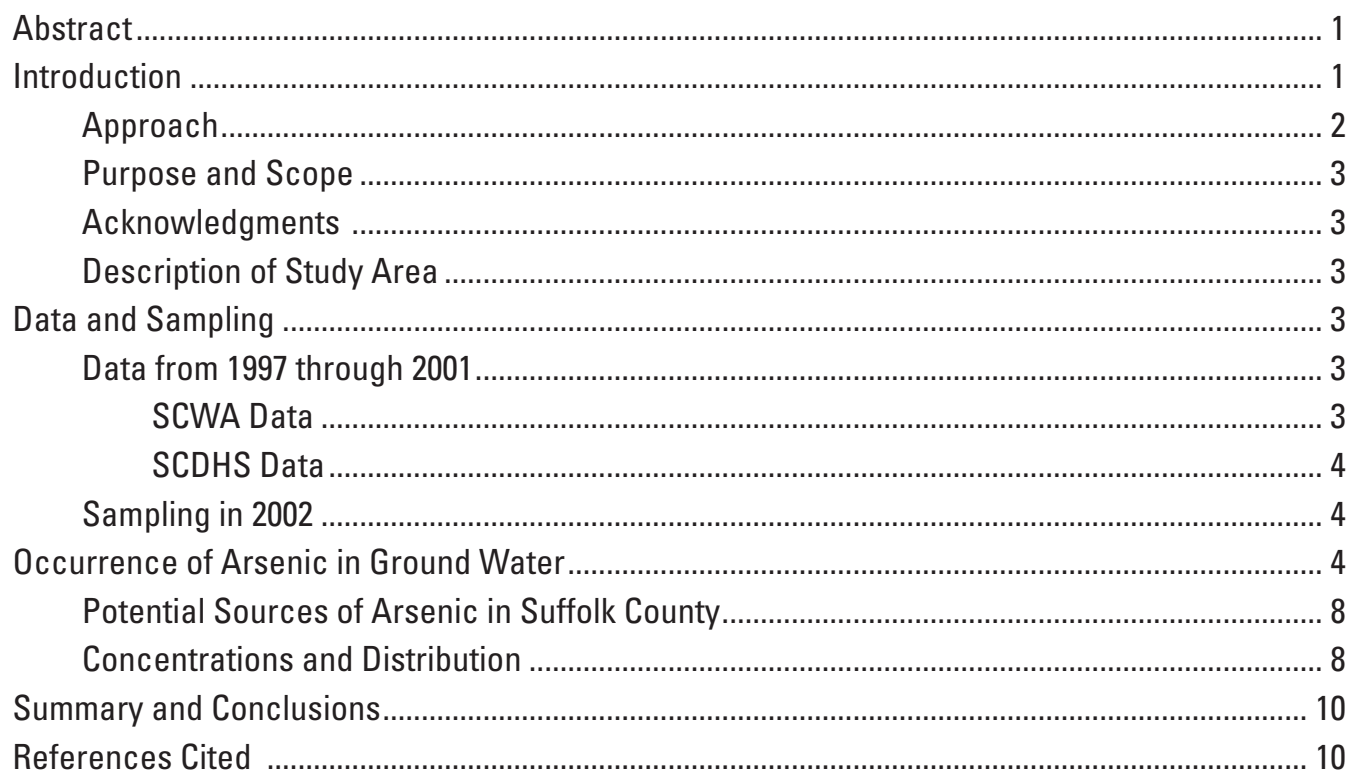

\section{Figures}

1. Map of Suffolk County, N.Y., showing locations of wells for which arsenic-concentration data from 1997 to 2002 are presented.

2. Map of Suffolk County, N.Y., showing land-use categories, locations of wells with reported arsenic concentrations exceeding 10 micrograms per liter, and locations of wells sampled during June through August 2002.

\section{Tables}

1. Suffolk County Water Authority (SCWA) wells with detectable arsenic concentrations, January 2000 through May 2002

2. Arsenic concentrations in ground-water samples collected by Suffolk County Department of Health Services, April 1997 through July 2001

3. Arsenic concentrations at selected wells in Suffolk County, N.Y., 1997 through 2002 ................. 9 
CONVERSION FACTORS, ABBREVIATIONS, AND VERTICAL DATUM

\begin{tabular}{lcl}
\hline Multiply & By & To obtain \\
\hline & Length & \\
foot $(\mathrm{ft})$ & 0.3048 & meter $(\mathrm{m})$ \\
mile $(\mathrm{mi})$ & 1.609 & kilometer $(\mathrm{km})$ \\
& & \\
& Other Abbreviations Used in this Report \\
& \multicolumn{2}{c}{ micrograms per liter $(\mu \mathrm{g} / \mathrm{L})$} \\
\hline
\end{tabular}

Vertical coordinate information is referenced to the National Geodetic Vertical Datum of 1929 (NGVD of 1929). 


\title{
Occurrence of Arsenic in Ground Water of Suffolk County, New York, 1997-2002
}

\author{
By Richard A. Cartwright
}

\section{Abstract}

Water-quality data from public and private drinkingwater supply wells that were sampled from October 1997 through March 2001 in Suffolk County, New York were evaluated to define the occurrence and concentrations of arsenic throughout the county. The data bases of the Suffolk County Water Authority (SCWA) and the Suffolk County Department of Health Services (SCDHS) included 14 wells at which arsenic concentrations approached or exceeded the 2002 U.S. Environmental Protection Agency (USEPA) drinking-water guideline of 10 micrograms per liter $(\mu \mathrm{g} / \mathrm{L})$.

As a followup, 19 wells were sampled from June through August 2002; 7 were wells previously reported to have had high arsenic concentrations; 7 were near other wells reported to have high concentrations, and the remaining 5 were in areas where detectable concentrations of arsenic were suspected. Arsenic concentrations near $10 \mu \mathrm{g} / \mathrm{L}$ were detected at only 2 of the 19 wells sampled; arsenic concentrations in samples from the remaining 17 wells were reported as less than the USGS Central Laboratory reporting limits of $2 \mu \mathrm{g} / \mathrm{L}$ or $4 \mu \mathrm{g} / \mathrm{L}$.

The elevated concentrations previously reported (1997 through 2001) for at least three of the wells were due to incompletely flushed carbon filters in the supply-well system or were typographical errors. A decrease in arsenic concentration was indicated at six of the seven resampled wells; no reasons are apparent. Arsenic concentrations in ground water that exceed drinking-water guidelines were found only at one site. On the basis of limited sampling data available for this study, the concentrations of arsenic above drinking-water standards $(10 \mu \mathrm{g} / \mathrm{L})$ do not appear to indicate a countywide problem with regards to arsenic concentrations in ground water.

\section{Introduction}

Long-term exposure to arsenic in drinking water has been linked to cancer of the bladder, lungs, skin, kidney, nasal passages, liver and prostate; other effects of arsenic ingestion include cardiovascular, pulmonary, immunological, neurological, and endocrine disorders (National Research Council, 1999). On February 22, 2002, the U.S. Environmental Protection Agency (USEPA) set a new standard for arsenic in drinking water to reduce public health risks; this new standard lowered the maximum concentration limit in drinking water from $50 \mu \mathrm{g} / \mathrm{L}$ to $10 \mu \mathrm{g} / \mathrm{L}$. Community water systems are required to meet this new standard by January 23, 2006 (U.S. Environmental Protection Agency, 2001b). The imposition of the new standard, and concern over potential health risks related to arsenic in drinking water, prompted reevaluations of public-water supplies across the nation.

An evaluation was conducted by the U.S. Geological Survey (USGS) to provide an overview of arsenic concentrations in ground water throughout the United States (Welch and others, 2000). Results indicated that 24 percent of the counties from which data were available reported arsenic concentrations exceeding $10 \mu \mathrm{g} / \mathrm{L}$ in at least 10 percent of the samples collected. The new USEPA standard for arsenic in drinking water, and results from Welch and others (2000), prompted an investigation by the USGS on Long Island, N.Y., in cooperation with Suffolk County's major water supplier, the Suffolk County Water Authority (SCWA), to document the occurrence and concentrations of arsenic in ground water throughout the county (fig. 1).

Long Island's ground-water system has been designated by the USEPA as a sole-source aquifer (SSA), which is defined as an aquifer that supplies at least 50 percent of the drinking water consumed in the overlying area and that, if contaminated, would create a significant hazard to public health (http://www.epa.gov/safewater/swp/ssa.html; accessed 5/21/03). Designation of Long Island's ground-water system as a sole-source aquifer requires that the USEPA review all proposed projects within the county that are receiving federal financial assistance; this review is intended to ensure that the projects do not endanger the water source. The designation of Long Island's ground-water system as a SSA is further justification for determining arsenic concentrations in ground water, in addition to the new USEPA arsenic standard, and results from Welch and others (2000). 


\section{Approach}

An inventory of data on arsenic concentrations in ground water from 1997 through 2001 was made from data bases of the USGS, SCWA, SCDHS, the New York State Department of Environmental Conservation (NYSDEC), and the Cornell Cooperative Extension of Suffolk County to (1) define the occurrence of arsenic detections, and (2) determine whether further study was warranted. Most of the arsenic-concentration data were found in the SCDHS and SCWA data bases; together these data bases provided a thorough areal coverage of Suffolk County.
Nineteen public and private drinking water-supply wells were selected for sampling and analysis. Fourteen of the wells had a reported history of arsenic concentrations close to, or exceeding, $10 \mu \mathrm{g} / \mathrm{L}$. Seven of these wells were sampled; the other seven were no longer available for resampling; therefore, seven nearby wells were sampled. The remaining five wells were in areas suspected to have potential for elevated arsenic concentrations on the basis of their down-gradient position in relation to other arsenic-contaminated wells or agricultural areas where past arsenic use was likely.

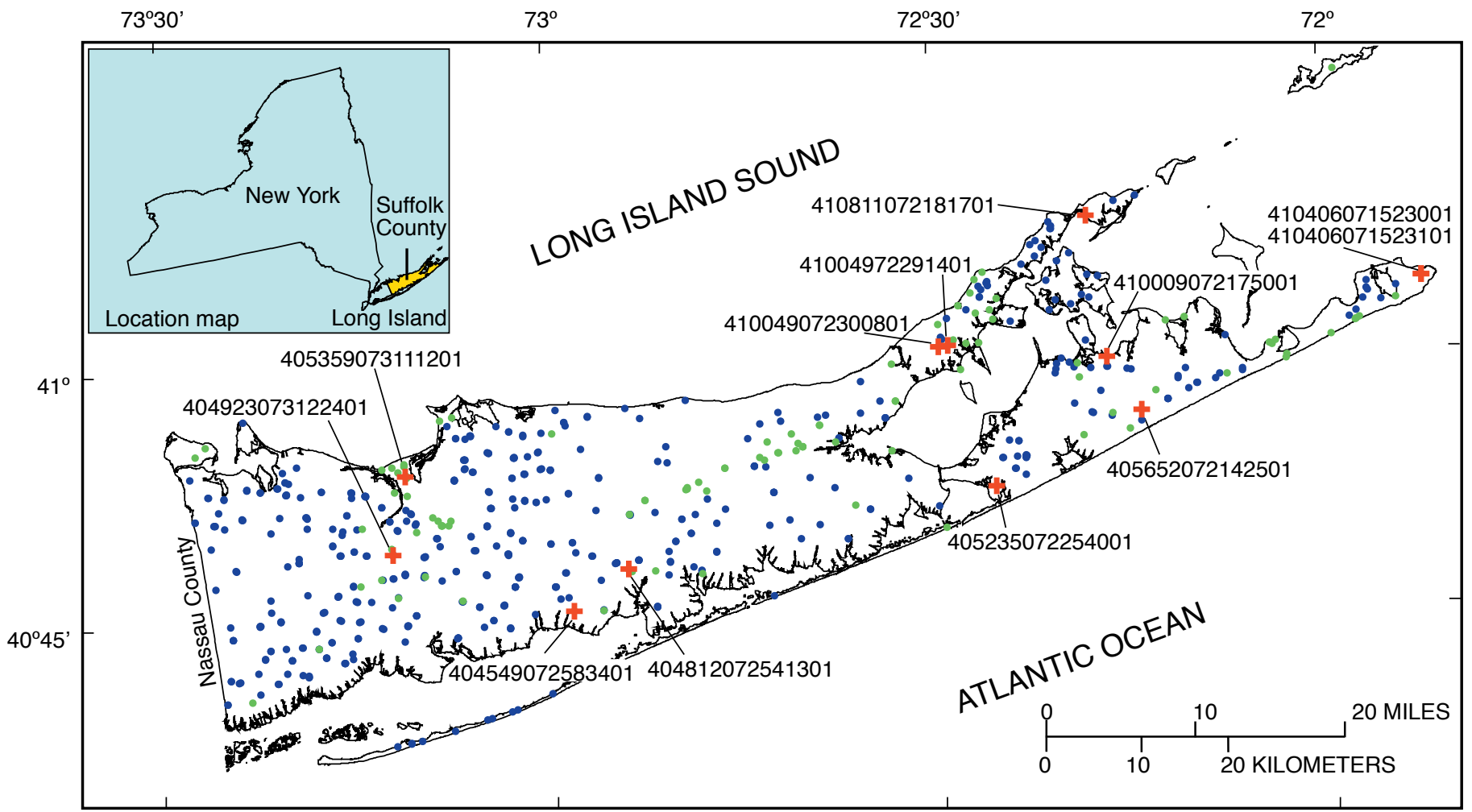

Base from U.S. Geological Survey digital data, 1:24,000,

Universal Transverse Mercator projection, NAD27, Zone 18

\section{EXPLANATION}

\section{SAMPLED WELLS}

- SAMPLES COLLECTED AND ANALYZED BY SCWA FROM JANUARY 2000 through MAY 2002 at which arsenic concentration was equal to or greater than $1 \mu \mathrm{g} / \mathrm{L}$ ( 514 wells)

- SAMPLES COLLECTED AND ANALYZED BY SCDHS FROM OCOTBER 1997 through APRIL 2001 at which arsenic concentration exceeded $2 \mu \mathrm{g} / \mathrm{L}$

+ WELL AT WHICH SCWA OR SCDHS ARSENIC CONCENTRATION DATA EXCEEDED $10 \mu \mathrm{g} / \mathrm{L}$
ABBREVIATIONS

SCDHS - Suffolk County Department of Health Services

SCWA - Suffolk County Water Authority

$\mu \mathrm{g} / \mathrm{L}$ - micrograms per liter

Figure 1. Locations of wells for which 1997-2002 arsenic-concentration data are presented. 


\section{Purpose and Scope}

This report summarizes arsenic-concentration data collected from October 1997 through March 2001 from public and private supply wells in Suffolk County. These data were compiled from several data bases and then compared with data from 19 public and private drinking-water supply wells that were sampled from June through August 2002. On the basis of the information compiled and the sampling performed in 2002, an assessment was made of the occurrence of arsenic in ground water in Suffolk County from 1997 through 2002. Analytical data are presented in three tables. Well locations and associated land uses are shown in maps.

\section{Acknowledgments}

Thanks are extended to Bob Murray, Karen Randazzo and Kevin Durk of the SCWA for cooperation during the sampling of public-supply wells and for providing historical water-quality data. The author also thanks Paul Ponturo of the SCDHS for providing historical water-quality data for private, community and non-community well samples.

\section{Description of Study Area}

Suffolk County occupies the eastern three-quarters of Long Island, N.Y. (fig.1) and extends about 85 miles eastward from the eastern boundary of Nassau County. The aquifer system beneath Suffolk County consists of a sequence of unconsolidated deposits comprising three aquifers that overlie a southeastward-dipping bedrock surface. Sediment thickness ranges from about 500 feet in the northwest to almost 2,000 feet beneath the barrier beaches in southwestern Suffolk County (Smolensky and others, 1989). The uppermost aquifer is the Pleistocene-aged upper glacial aquifer, which is about 700 feet thick in the northern half of the island and generally thins to about 100 feet thick in the south. It is found within the upper Pleistocene deposits, which consist primarily of two terminal moraines, outwash, glaciolacustrine deposits, and marine clay on the extreme south shore (Pluhowski and Kantrowitz, 1964). Till, an unsorted mixture of clay, sand, gravel and boulders, is found mostly along the north shore and in the moraines. Outwash deposits that consist of fine to very coarse quartzose sand and gravel are found between and south of the moraines. Glaciolacustrine deposits that consist of silt, clay, and some sand and gravel are found mostly in central and eastern Suffolk County. Most private wells in the county are completed in the upper glacial aquifer.

Below the upper glacial aquifer is the Cretaceous-aged Magothy aquifer, which ranges in thickness from 0 in extreme northwestern Suffolk County to more than 1,000 feet in the south and extends as deep as 1,200 feet below land surface (Smolensky and others, 1989). The Magothy aquifer is within the Magothy Formation and Matawan Group, undifferentiated, and it consists of fluviodeltaic sediments deposited in a coastal plain environment. Sediments in the Magothy aquifer include fine to medium sand, clayey in part, with interbedded lenses and layers of coarse sand and sandy and solid clay. Gravel is common in the basal 50 to 200 feet (McClymonds and Franke, 1972). The Magothy aquifer is generally less affected by surface contamination than the upper glacial aquifer and is more commonly tapped by public-water suppliers.

The deepest aquifer (Lloyd aquifer) is part of the Cretaceous-aged Raritan Formation and is separated from the Magothy aquifer by the Raritan confining unit. There are very few public-supply wells that penetrate the Lloyd aquifer. It is not discussed further in this report.

\section{Data and Sampling}

Data bases of the USGS, SCWA, SCDHS, New York State Department of Environmental Conservation (NYSDEC), and the Cornell Cooperative Extension of Suffolk County were reviewed for arsenic records from 1997-2001; the results prompted a reconnaissance and resampling in 2002. A discussion of SCWA and SCDHS sampling and analyzing techniques is not included in this report because these data are not being used to compare with USGS-collected data; they are only used to aid in selecting sampling sites.

\section{Data from 1997 through 2001}

Most of the reported detections of arsenic in ground water were found in the SCDHS data base, probably because SCDHS often collects water-quality data from areas with a history or a potential of contamination, whereas SCWA installs production wells in areas that are likely to yield uncontaminated water. Any SCWA production well that contains unacceptable concentrations of arsenic (or any other contaminant) is taken out of service until the situation is remedied; this, in effect, minimizes the number of arsenic detections in the SCWA data base.

Locations of wells from which arsenic data from 1997 through 2002 were available are shown in figure 1. Only wells at which concentrations exceeded $2 \mu \mathrm{g} / \mathrm{L}$ (from SCDHS's supply-well data) are shown because inclusion of all 12,743 wells would make the map unreadable.

\section{SCWA Data}

A review of SCWA's arsenic-concentration data from 2000 through 2002 for 514 untreated supply-well samples identified only 24 wells with arsenic concentrations equal to or greater than the detection limit of $1 \mu \mathrm{g} / \mathrm{L}$, and only two that had concentrations near the new USEPA Drinking Water Guideline of $10 \mu \mathrm{g} / \mathrm{L}$ (table 1). Locations of SCWA wells with arsenic-concentration data are included in figure 1. 
Table 1. Untreated supply-well samples collected and analyzed by Suffolk County Water Authority (SCWA), with detectable arsenic concentrations (equal to or greater than $1 \mu \mathrm{g} / \mathrm{L}$ ), January 2000 through May 2002, Suffolk County, New York.

[Sampling was done at 514 supply wells; (mo/d/yr), month/day/year; $\mu \mathrm{g} / \mathrm{L}$, micrograms per liter. Boldface indicates arsenic concentration near or above $10 \mu \mathrm{g} / \mathrm{L}$.

\begin{tabular}{|c|c|c|c|}
\hline Hamlet & $\begin{array}{l}\text { Well } \\
\text { No. }\end{array}$ & $\begin{array}{c}\text { Sample date } \\
\text { (mo/d/yr) }\end{array}$ & $\begin{array}{c}\text { Arsenic } \\
\text { concentration } \\
(\mu \mathrm{g} / \mathrm{L})\end{array}$ \\
\hline Middle Island & S-49606 & 04/09/02 & 1 \\
\hline Wading River & S-100608 & 02/07/02 & 1 \\
\hline West Babylon & S-51457 & $01 / 28 / 02$ & 1 \\
\hline Southampton & SCUMW1 & $04 / 12 / 00$ & 1.1 \\
\hline Mastic & S-71881 & $02 / 18 / 02$ & 1.2 \\
\hline Mastic & S-71882 & $04 / 19 / 02$ & 1.2 \\
\hline Lakeland & S-77010 & 07/19/00 & 1.2 \\
\hline Sag Harbor & DIVWM & $04 / 12 / 00$ & 1.3 \\
\hline Sag Harbor & DIVWM4 & $01 / 12 / 00$ & 1.3 \\
\hline West Islip & S-101321 & $02 / 02 / 02$ & $* 1.4$ \\
\hline Bohemia & S-67074 & $05 / 04 / 02$ & 1.5 \\
\hline Central Islip & S-67197 & $02 / 27 / 02$ & 1.6 \\
\hline Smithtown & S-106565 & $04 / 15 / 02$ & $* 1.6$ \\
\hline Bohemia & S-68690 & $01 / 21 / 02$ & 1.6 \\
\hline Oakville & S-108161 & $01 / 20 / 02$ & $* 1.6$ \\
\hline Yaphank & S-47438 & 05/07/02 & 1.6 \\
\hline Oakville & S-94286 & $01 / 21 / 02$ & $* 1.8$ \\
\hline Southampton & S-79293 & $04 / 12 / 00$ & 1.9 \\
\hline Southold & S-106416 & $04 / 19 / 00$ & $* 3.3$ \\
\hline Central Islip & S-74505 & $01 / 21 / 02$ & 3.8 \\
\hline Southampton & S-106976 & $04 / 12 / 00$ & $* 4.2$ \\
\hline West Islip & S-22389 & 02/03/02 & 4.4 \\
\hline Montauk & S-76305 & $02 / 25 / 02$ & 8 \\
\hline Montauk & S-76304 & $04 / 23 / 02$ & 10.2 \\
\hline
\end{tabular}

*Well not plotted in figure 1 because coordinates are not available

\section{SCDHS Data}

A review of data collected from 1997 through 2001 from the 12,743 supply-well samples in the SCDHS data base indicated only 227 samples with arsenic concentrations greater than the detection limit of $1 \mu \mathrm{g} / \mathrm{L}$. Most samples are from untreated ground water, but some were collected after the water had passed through a carbon filtration system. Many samples had arsenic concentrations between $1 \mu \mathrm{g} / \mathrm{L}$ and 2 $\mu \mathrm{g} / \mathrm{L}$, therefore, only samples with concentrations exceeding $2 \mu \mathrm{g} / \mathrm{L}$, and the well locations, are listed in table 2. Arsenicconcentration data were also reviewed from test-well samples collected and analyzed by the SCDHS as part of a 19972002 pesticide-occurrence study done in cooperation with the NYSDEC. That study also included the public-supplywell data mentioned above. The data are reported in three documents resulting from three consecutive investigations beginning in 1997; these are available on the NYSDEC web page-http://www.dec.state.ny.us/website/dshm/prl/scdhs1c. htm (accessed 05/21/03), in Bradley and others (2000), and in Bradley and others (2002). The following detections (at the minimum reporting level of $2 \mu \mathrm{g} / \mathrm{L}$ ) were reported for the following periods of the pesticide-occurrence study:

Most arsenic concentrations were below $10 \mu \mathrm{g} / \mathrm{L}$. Data

\begin{tabular}{ll}
\hline October 1997 through March 1999: & 42 detections in 1,867 wells \\
April 1999 through March 2000: & 5 detections in 743 wells \\
April 2000 through March 2001: & 11 detections in 1,099 wells \\
\hline
\end{tabular}

from these three sources that were not in the SCDHS data base had little site information and are not included in this report.

\section{Sampling in 2002}

Initially, 14 wells with reported arsenic concentrations ranging from $8 \mu \mathrm{g} / \mathrm{L}$ to $93.5 \mu \mathrm{g} / \mathrm{L}$ during 1997 through 2001 were selected from the SCWA and SCDHS data sets possible sample collection in 2002. Some of the homes served by these wells had been recently connected to a public water supply, and their wells were no longer accessible for sampling. Where this occurred, a sample was collected from a neighboring site if possible. Additional wells were selected for sampling on the basis of their proximity to sites with previously reported arsenic concentrations greater than $10 \mu \mathrm{g} / \mathrm{L}$. These included wells downgradient from agricultural land and wells downgradient of till deposits in which elevated arsenic concentrations were reported.

In all, 19 wells ( 3 public supply, 12 private, 3 community supply, and 1 noncommunity supply) were sampled from June through August 2002 and analyzed for arsenic and other metals at the USGS National Water Quality Laboratory (NWQL) in Denver, Colo., for comparison with the 1997 through 2001 data. Locations of these 19 wells are plotted on the land-use map shown in figure 2. Water samples were collected from spigots as close to the wellhead as possible and ahead of any filtering systems. Samples were collected only after enough water had been run to allow stabilization of temperature, $\mathrm{pH}$, and specific conductance, so that the sample would be as representative of ground-water quality as possible. Samples were collected, treated, and filtered in accordance with NWQL protocols, then packed in ice and shipped overnight to NWQL for analysis. Arsenic concentration was measured by graphite furnace-atomic absorption spectrometry (Jones and Garbarino, 1999). Duplicate samples were collected and analyzed at two sites by SCWA (termed split samples in table 3 ).

\section{Occurrence of Arsenic in Ground Water}

Arsenic is a naturally occurring element in certain types of bedrock. Geochemical reactions within fractured bedrock can release arsenic into ground water. Arsenic can be 
Table 2. Arsenic concentrations greater than $2 \mu \mathrm{g} / \mathrm{L}$ in ground-water samples collected from April 1997 through July 2001 and analyzed by Suffolk County Department of Health Services (SCDHS), Suffolk County, New York.

[NCOM, noncommunity supply well (serves schools, hotels, restaurants, etc.); PRIV, private supply well; COMM, community supply well (serves small community); (mo/d/ yr), month/day/year; $\mu \mathrm{g} / \mathrm{L}$, micrograms per liter. Boldface indicates arsenic concentration near to or exceeding $10 \mu \mathrm{g} / \mathrm{L}$.]

\begin{tabular}{|c|c|c|c|c|}
\hline Hamlet & Well No. & $\begin{array}{l}\text { Type of } \\
\text { site }\end{array}$ & $\begin{array}{l}\text { Sample date } \\
\text { (mo/d/yr) }\end{array}$ & $\begin{array}{l}\text { Arsenic } \\
\text { concentration } \\
(\mu \mathrm{g} / \mathrm{L})\end{array}$ \\
\hline Amagansett & & NCOM & $8 / 25 / 99$ & 3.03 \\
\hline Amagansett & & PRIV & $4 / 12 / 99$ & 2.83 \\
\hline Amagansett & & PRIV & $8 / 5 / 98$ & 2.39 \\
\hline Amagansett & & PRIV & $1 / 11 / 99$ & 2.38 \\
\hline Amagansett & & PRIV & $6 / 5 / 00$ & 2.53 \\
\hline Bellport & S-14710 & COMM & $11 / 15 / 99$ & 2.07 \\
\hline Bohemia & S-67074 & COMM & $4 / 21 / 99$ & 2.4 \\
\hline Brentwood & S-30234 & СОММ & $5 / 7 / 01$ & 8.8 \\
\hline Bridgehampton & & PRIV & $9 / 14 / 98$ & 4.02 \\
\hline Brookhaven & & PRIV & $11 / 22 / 99$ & 6.64 \\
\hline Brookhaven & & PRIV & 4/17/00 & 82 \\
\hline Brookhaven & & PRIV & $5 / 9 / 00$ & 3.77 \\
\hline Calverton & & PRIV & $11 / 12 / 98$ & 3.72 \\
\hline Calverton & & PRIV & $10 / 14 / 98$ & 2.72 \\
\hline Calverton & & PRIV & $4 / 27 / 00$ & 2.09 \\
\hline Calverton & $\mathrm{X}-00050$ & COMM & $7 / 11 / 00$ & 3.25 \\
\hline Center Moriches & & PRIV & $3 / 17 / 99$ & 2.94 \\
\hline Central Islip & S-67197 & COMM & $6 / 14 / 01$ & 2.3 \\
\hline Central Islip & S-74505 & COMM & $3 / 17 / 99$ & 3.91 \\
\hline Copiague & S-113006 & COMM & 8/23/99 & 2.08 \\
\hline Cutchogue & & NCOM & $8 / 14 / 00$ & 2.39 \\
\hline Cutchogue & & NCOM & $5 / 19 / 98$ & 2.95 \\
\hline Cutchogue & & PRIV & $3 / 13 / 98$ & 43.5 \\
\hline Cutchogue & & PRIV & $7 / 28 / 97$ & 2.6 \\
\hline Cutchogue & & PRIV & $11 / 5 / 98$ & 43.7 \\
\hline Cutchogue & & PRIV & $3 / 27 / 00$ & 2.66 \\
\hline East Hampton & & PRIV & $5 / 7 / 98$ & 2.2 \\
\hline East Hampton & & PRIV & $8 / 23 / 99$ & 2.03 \\
\hline East Hampton & & PRIV & $8 / 23 / 99$ & 2.12 \\
\hline East Patchogue & & PRIV & $6 / 8 / 00$ & 18.3 \\
\hline Fishers Island & S-92463 & COMM & $6 / 19 / 01$ & 2.3 \\
\hline Hampton Bays & & NCOM & $8 / 5 / 98$ & 3.97 \\
\hline Hampton Bays & & PRIV & $3 / 21 / 00$ & 3.83 \\
\hline Hauppauge & S-15746 & COMM & $5 / 7 / 01$ & 28 \\
\hline Laurel & & PRIV & $6 / 19 / 00$ & 5.83 \\
\hline Laurel & & PRIV & $6 / 26 / 00$ & 2.65 \\
\hline Lloyd Harbor & & PRIV & $4 / 10 / 01$ & 4.1 \\
\hline Lloyd Neck & & PRIV & $4 / 10 / 01$ & 5.8 \\
\hline Manorville & & NCOM & $3 / 14 / 00$ & 4.47 \\
\hline Manorville & & PRIV & $4 / 25 / 97$ & 2.9 \\
\hline Manorville & & PRIV & $5 / 21 / 97$ & 2.4 \\
\hline Manorville & & PRIV & $8 / 11 / 97$ & 2.5 \\
\hline Manorville & & PRIV & $8 / 11 / 97$ & 3 \\
\hline Manorville & & PRIV & $8 / 12 / 97$ & 4.8 \\
\hline Manorville & & PRIV & $8 / 12 / 97$ & 5.6 \\
\hline Mattituck & & PRIV & $7 / 14 / 98$ & 4.3 \\
\hline Montauk & & NCOM & 8/23/99 & 2.07 \\
\hline Montauk & & NCOM & $8 / 23 / 99$ & 2.23 \\
\hline
\end{tabular}


Table 2. (Continued) Arsenic concentrations greater than $2 \mu \mathrm{g} / \mathrm{L}$ in ground-water samples collected from April 1997 through July 2001 and analyzed by Suffolk County Department of Health Services (SCDHS), Suffolk County, New York.

\begin{tabular}{|c|c|c|c|c|}
\hline Hamlet & Well No. & $\begin{array}{l}\text { Type of } \\
\text { site }\end{array}$ & $\begin{array}{l}\text { Sample date } \\
\text { (mo/d/yr) }\end{array}$ & $\begin{array}{l}\text { Arsenic } \\
\text { concentration } \\
(\mu \mathrm{g} / \mathrm{L}) \\
\end{array}$ \\
\hline Montauk & & NCOM & $8 / 23 / 99$ & 2.17 \\
\hline Montauk & & NCOM & $8 / 23 / 99$ & 2.06 \\
\hline Montauk & & NCOM & $8 / 23 / 99$ & 2.22 \\
\hline Mount Sinai & & PRIV & $5 / 11 / 00$ & 3.28 \\
\hline Nesconset & & PRIV & $6 / 23 / 97$ & 5.7 \\
\hline Nesconset & & PRIV & $3 / 10 / 98$ & 7.29 \\
\hline Nesconset & & PRIV & $5 / 20 / 98$ & 7.84 \\
\hline Nesconset & & PRIV & $5 / 20 / 98$ & 6.19 \\
\hline Nesconset & & PRIV & $5 / 21 / 98$ & 7.75 \\
\hline Nesconset & & PRIV & $6 / 25 / 98$ & 8.16 \\
\hline Nesconset & & PRIV & $4 / 17 / 00$ & 3.75 \\
\hline New Suffolk & & NCOM & $8 / 18 / 99$ & 2.1 \\
\hline Nissequogue & & PRIV & $10 / 1 / 97$ & 20.5 \\
\hline Nissequogue & & PRIV & $2 / 19 / 98$ & 2.25 \\
\hline Nissequogue & & PRIV & $3 / 3 / 98$ & 5.87 \\
\hline Nissequogue & & PRIV & $6 / 22 / 98$ & 3.53 \\
\hline Nissequogue & & PRIV & 8/6/98 & 6.64 \\
\hline Nissequogue & & PRIV & 8/6/98 & 4.48 \\
\hline Oakville & S-94286 & COMM & $4 / 18 / 01$ & 2.4 \\
\hline Old Field & & PRIV & 8/6/98 & 3.03 \\
\hline Orient & & NCOM & 6/8/00 & 93.5 \\
\hline Peconic & & NCOM & $5 / 14 / 01$ & 2.4 \\
\hline Peconic & & PRIV & $7 / 29 / 97$ & 3.9 \\
\hline Peconic & & PRIV & $2 / 6 / 01$ & 3.5 \\
\hline Riverhead & & COMM & $8 / 31 / 98$ & 3.02 \\
\hline Riverhead & & PRIV & 8/4/97 & 2.9 \\
\hline Riverhead & & PRIV & $3 / 13 / 00$ & 6.45 \\
\hline Riverhead & S-01322 & COMM & $4 / 3 / 00$ & 3.66 \\
\hline Riverhead & S-07261 & COMM & $7 / 25 / 01$ & 4.3 \\
\hline Riverhead & S-111777 & COMM & $7 / 25 / 01$ & 2.9 \\
\hline Riverhead & S-15117 & COMM & $9 / 15 / 99$ & 2.65 \\
\hline Riverhead & S-30271 & COMM & $7 / 25 / 01$ & 2 \\
\hline Riverhead & S-66685 & COMM & 7/19/00 & 3.04 \\
\hline Riverhead & S-88466 & COMM & $7 / 25 / 01$ & 4.2 \\
\hline Riverhead & X-00041 & COMM & $7 / 11 / 00$ & 2.98 \\
\hline Sag Harbor & & NCOM & 6/2/99 & 55.4 \\
\hline Sag Harbor & & PRIV & $6 / 11 / 97$ & 2.5 \\
\hline Sag Harbor & S-36860 & COMM & $9 / 14 / 98$ & 4.17 \\
\hline Sagaponack & & PRIV & $5 / 5 / 98$ & 2.17 \\
\hline Sagaponack & & PRIV & $6 / 25 / 98$ & 4.04 \\
\hline Saint James & & PRIV & $8 / 20 / 97$ & 2.4 \\
\hline Saint James & & PRIV & 3/30/98 & 3.33 \\
\hline Saint James & & PRIV & $11 / 30 / 99$ & 3.98 \\
\hline Setauket & & PRIV & $12 / 18 / 97$ & 2.86 \\
\hline Shirley & & PRIV & 8/6/98 & 3.66 \\
\hline Smithtown & & NCOM & $8 / 8 / 00$ & 6.26 \\
\hline Smithtown & & PRIV & $9 / 16 / 97$ & 2.2 \\
\hline Smithtown & & PRIV & $5 / 20 / 98$ & 2.71 \\
\hline Smithtown & & PRIV & $8 / 6 / 98$ & 3.18 \\
\hline Smithtown & & PRIV & $11 / 13 / 00$ & 2.71 \\
\hline Southampton & & PRIV & 4/7/98 & 34.3 \\
\hline
\end{tabular}


Table 2. (Continued) Arsenic concentrations greater than $2 \mu \mathrm{g} / \mathrm{L}$ in ground-water samples collected from April 1997 through July 2001 and analyzed by Suffolk County Department of Health Services (SCDHS), Suffolk County, New York.

\begin{tabular}{|c|c|c|c|c|}
\hline Hamlet & Well No. & $\begin{array}{l}\text { Type of } \\
\text { site }\end{array}$ & $\begin{array}{l}\text { Sample date } \\
\text { (mo/d/yr) }\end{array}$ & $\begin{array}{l}\text { Arsenic } \\
\text { concentration } \\
(\mu \mathrm{g} / \mathrm{L})\end{array}$ \\
\hline Southold & & PRIV & $10 / 2 / 99$ & 2.11 \\
\hline Southold & & PRIV & 7/7/99 & 5.61 \\
\hline Southold & & PRIV & $4 / 25 / 00$ & 2.18 \\
\hline Southold & & PRIV & $2 / 29 / 00$ & 7.54 \\
\hline Southold & & PRIV & $7 / 5 / 01$ & 7.2 \\
\hline Springs & & NCOM & $8 / 7 / 00$ & 2.3 \\
\hline Upton & S-22150 & COMM & $8 / 16 / 00$ & 3.14 \\
\hline Upton & S-66944 & COMM & $8 / 16 / 00$ & 2.59 \\
\hline Wainscott & & PRIV & $6 / 29 / 00$ & 24.7 \\
\hline West Islip & S-22389 & COMM & $3 / 1 / 01$ & 4.1 \\
\hline Yaphank & S-47438 & COMM & $9 / 26 / 00$ & 2.28 \\
\hline
\end{tabular}

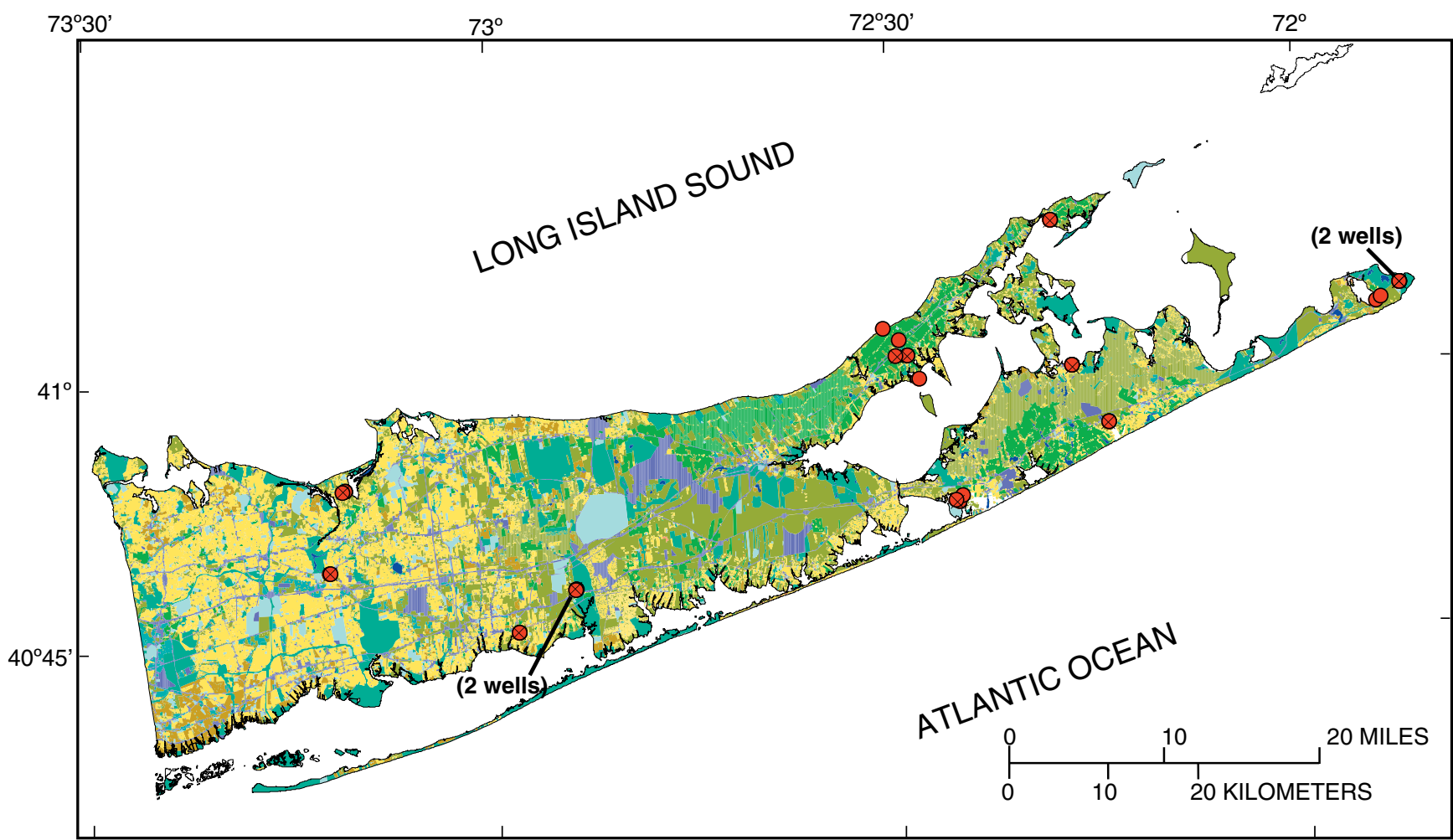

Base from U.S. Geological Survey digital data, 1:24,000,

Universal Transverse Mercator projection, NAD27, Zone 18

\section{EXPLANATION}

Well sampled by USGS from June-August 2002

Arsenic concentration exceeded $10 \mu \mathrm{g} / \mathrm{L}$ in 1997 through 2001

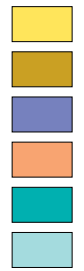

$<1$ to 4 dwelling unit per acre 5 to $<11$ dwelling unit per acre Commercial

Commercial Recreational Industrial

Open space and recreational Agricultural Transportation and utilities Vacant

Freshwater bodies

Institutional

Figure 2. Land-use categories in Suffolk County, N.Y., and locations of wells at which historical arsenic concentrations in ground water exceeded 10 micrograms per liter, and wells that were sampled during the June-August, 2002 investigation. 
released from arsenic-bearing iron oxides under reducing conditions (Nickson and others, 1998) and can be weathered from arsenic-bearing sulfide minerals in oxidizing environments (Brown and Chute, 2002). Similar geochemical processes can occur in unconsolidated deposits containing these arsenic sources. Reducing conditions are most common in deep aquifers and near ground-water discharge zones, and oxidizing conditions are more typical of shallow aquifers and near pumping wells that draw oxygen-rich water into deeper zones. Runoff from sulfide-rich mine tailings is a source of arsenic in some parts of the United States.

Manmade sources of arsenic in ground water include industrial and agricultural products. Nationwide, 90 percent of the arsenic produced for industrial purposes is used in wood preservatives; the rest is used in paints, dyes and metals, drugs, soaps, and semiconductors (U.S. Environmental Protection Agency, 2001a). Agricultural sources include certain fertilizers and pesticides.

\section{Potential Sources of Arsenic in Suffolk County}

Suffolk County has few of the potential sources of arsenic mentioned above. A bedrock source is unlikely because the depth to bedrock in the area of the 19 wells sampled in 2002 ranges from about 600 to 1,700 feet below sea level, and most of these wells are screened far above the bedrock. Other naturally occurring rock sources of arsenic are unlikely because most wells are screened in deposits of reworked fluviodeltaic sediments and outwash, where most reactive minerals have been removed by geochemical processes. Two possible exceptions are the SCWA supply wells S-76304 and S-76305, which penetrate till where cobbles and boulders could potentially provide a source of arsenic. Industrial sources are unlikely because past and current land-use practices tend toward residential, farming, and open space (fig. 2).

The most likely sources of arsenic in Suffolk County are geochemical reactions involving arsenic-bearing minerals within the unconsolidated deposits, and agricultural products. Sodium arsenite (an herbicide) and lead arsenate (an insecticide) were applied to farmland on Long Island until their use was curtailed in 1978, but most agricultural uses of arsenic compounds were not banned by the EPA until 1988. Therefore, the large areas of land in Suffolk County's eastern end that were previously farmed, or that are still being farmed (fig. 2), could be or have been a source of arsenic in ground water. Soils collected from agricultural areas in Suffolk County in which arsenic-bearing pesticides were previously used were reported by the Cornell Cooperative Extension to contain arsenic concentrations ranging from $27.8 \mu \mathrm{g} / \mathrm{L}$ to $51 \mu \mathrm{g} / \mathrm{L}$ (Sanok and others, 1995). In contrast, an experiment in which recycled municipal waste, a known source of arsenic, was applied to sod farms in Suffolk County, found arsenic in the soil, but not in the ground water (W. J. Sanok, Cornell Cooperative Extension, oral commun., 2002). This may have been because arsenic tends to sorb onto organic particles and clays and can thereby be prevented from leaching into ground water.

\section{Concentrations and Distribution}

Data on 24 selected wells are presented in table 3. Thirteen of these sampled from August 1997 through May 2001 contained arsenic concentrations approaching or exceeding $10 \mu \mathrm{g} / \mathrm{L}$. Data from 19 wells sampled in 2002 are also listed. In 2002 only 7 of the 13 wells sampled earlier were resampled because some wells had been shut down; 7 other wells were sampled at locations close to previously sampled wells; and 5 wells were sampled in areas suspected of having arsenic contamination. The concentrations measured by SCWA and SCDHS at the selected wells during 1997 through 2001 ranged from $8 \mu \mathrm{g} / \mathrm{L}$ to $93.5 \mu \mathrm{g} / \mathrm{L}$, whereas those measured by USGS in 2002 ranged from less than $2 \mu \mathrm{g} / \mathrm{L}$ to $11 \mu \mathrm{g} / \mathrm{L}$ (table 3).

Only 2 of the 19 samples collected during 2002 had arsenic concentrations that approached the USEPA standard of $10 \mu \mathrm{g} / \mathrm{L}$ (table 3); these were the SCWA supply wells S-76304 (USGS well identifier 410406071523001) with an arsenic concentration of $11 \mu \mathrm{g} / \mathrm{L}$, and S-76035 (USGS well identifier 410406071523101) with an arsenic concentration of $7 \mu \mathrm{g} / \mathrm{L}$. These wells are adjacent to each other and screened at similar depths (table 2) and, therefore, reflect conditions at one site. The reasons for the concentration discrepancies between the two sampling periods (table 3) are varied: (1) the elevated concentrations at the SCWA well S-15746 (USGS well identifier 404923073122401) and at the private supply well (USGS well identifier 410811072181701) in 1997 through 2001 are attributed to improperly flushed carbon filters (carbon used in water filters is a source of arsenic); (2) the elevated arsenic concentration at the private supply well (USGS well identifier 410049072291401) in 1998 is a typographical error reported by SCDHS; and (3) the apparent changes at other wells (table 3 ) are unknown but may reflect the passing of localized contaminant plumes, although no data are available to support this. Future sampling could be done downgradient of these wells to test this hypothesis.

Locations of the five sites sampled in 2002 but not during 1997 through 2001 are as follows: one is at a landfill, one is about 1500 feet downgradient from that landfill, one is near a ground-water-discharge zone in an agricultural area, and two are near a ground-water-discharge zone in till deposits similar to those at SCWA supply wells S-76304 and S-76305. None of these five wells showed arsenic contamination. 
Table 3. Arsenic concentrations at selected wells in Suffolk County, N.Y., 1997 through 2002.

[Lat.-Long., latitude and longitude in degrees and minutes; (mo/d/yr), month/day/year; $\mu \mathrm{g} / \mathrm{L}$, micrograms per liter; --, no measurement; <, less than.]

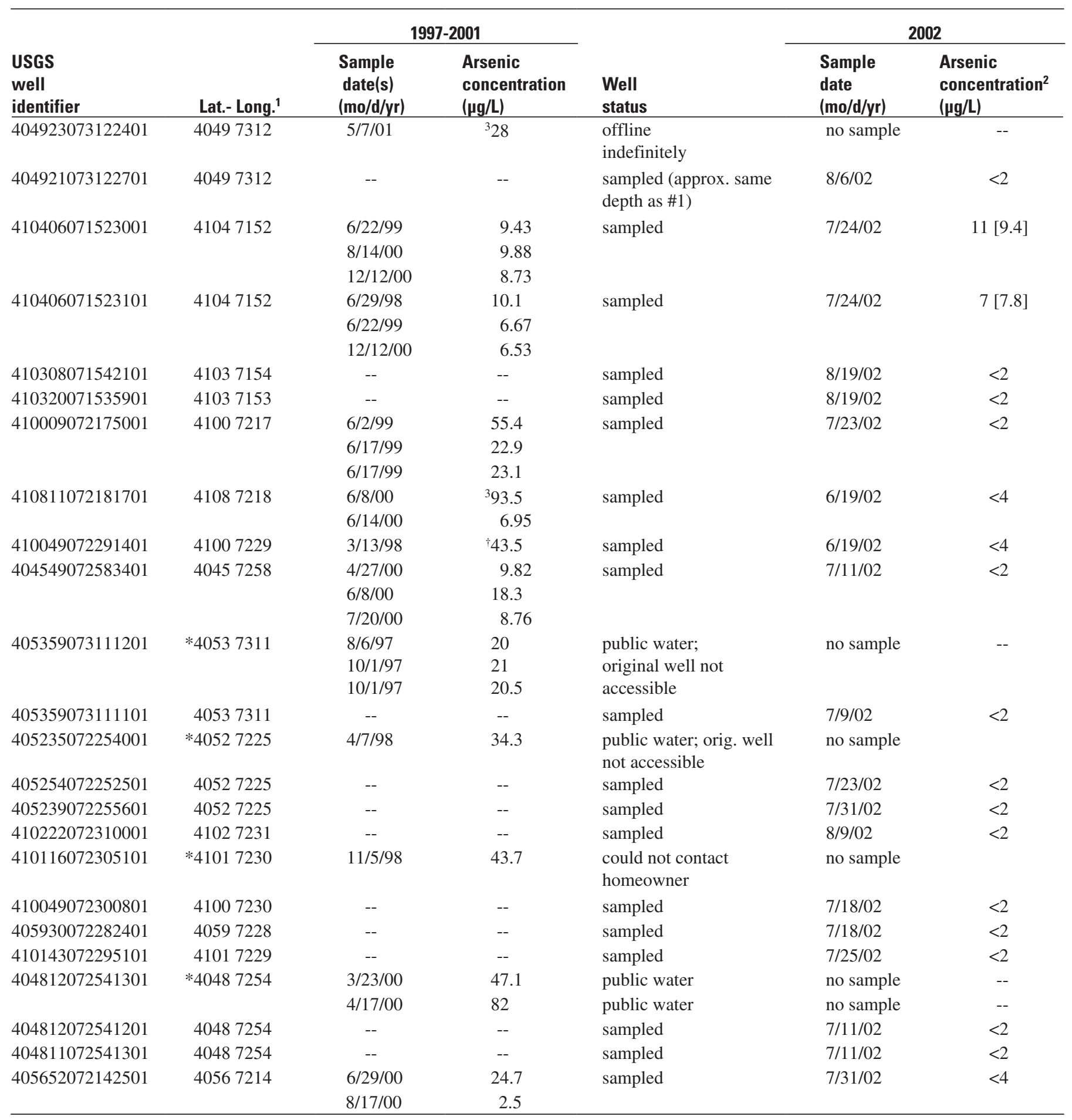

1 Coordinates with an asterisk $(*)$ are approximate well locations

2 Numbers in brackets are from split samples collected and analyzed by Suffolk County Water Authority

3 Elevated concentration due to new, incompletely flushed carbon filter

† Typographical error in Suffolk County Department of Health Services data base 


\section{Summary and Conclusions}

Long-term exposure to arsenic in drinking water has been linked to several types of cancer and other health-related problems (National Research Council, 1999). On February 22, 2002, the USEPA set a new standard for arsenic in drinking water to reduce public health risks; this new standard lowered the maximum concentration limit in drinking water from $50 \mu \mathrm{g} / \mathrm{L}$ to $10 \mu \mathrm{g} / \mathrm{L}$.

In 2001 the USGS on Long Island, N.Y., in cooperation with Suffolk County's major water supplier, the Suffolk County Water Authority (SCWA), began an investigation to document the occurrence and concentrations of arsenic in ground water throughout Suffolk County. First, an inventory of data on arsenic concentrations in ground water from 1997 through 2001 was made from data bases of the USGS, SCWA, SCDHS, the New York State Department of Environmental Conservation (NYSDEC), and the Cornell Cooperative Extension of Suffolk County to (1) define the occurrence of arsenic detections, and (2) determine whether further study was warranted. Secondly, based on the results from the inventory, nineteen wells were selected for additional sampling and water-quality analyses.

Fourteen of the supply wells sampled from 1997 through 2001 had a reported history of arsenic concentrations close to, or exceeding, $10 \mu \mathrm{g} / \mathrm{L}$. An attempt was made to resample these wells in 2002. Seven were resampled; the other seven were no longer available for sampling, therefore, seven nearby wells were sampled. Five additional wells that were in areas suspected to have potential for elevated arsenic concentrations on the basis of their down-gradient position in relation to other arsenic-contaminated wells or agricultural areas where past arsenic use was likely were also sampled.

On the basis of the limited 2002 sampling data available for this study the concentrations of arsenic above drinking water standards $(10 \mu \mathrm{g} / \mathrm{L})$ do not appear to indicate a countywide problem in ground water in Suffolk County. Only two wells (located at one site) of 19 wells suspected of having arsenic contamination that were sampled in $2002 \mathrm{had}$ arsenic concentrations near the EPA limit of $10 \mu \mathrm{g} / \mathrm{L}$. These were SCWA supply wells S-76304 (USGS well identifier 410406071523001) and S-76035 (USGS well identifier 410406071523101). It should be noted that SCWA does not include a supply well in its distribution system unless arsenic concentrations are less than $5 \mu \mathrm{g} / \mathrm{L}$ (K. A. Randazzo, Laboratory Director, SCWA, oral commun., 2002). The paucity of wells with elevated arsenic concentrations in 2002 does not rule out the possibility of unknown, localized arsenic concentrations that exceed $10 \mu \mathrm{g} / \mathrm{L}$. Aquifer zones with arsenic-bearing iron-oxides or sulfide minerals can be a source of arsenic under oxidizing and reducing conditions, respectively. The geochemical data collected during this study are too limited to support or refute geochemical reactions within the aquifers as a source of arsenic. Future investigations could include sampling wells screened in aquifer zones that contain potentially arsenic-rich ferric hydroxides under reducing conditions, and iron sulfides under oxidizing conditions.

The SCDHS's sampling programs during 1997 through 2001 were directed toward specific areas considered to be vulnerable to pesticide contamination; thus, the data from these sampling programs are biased and would be expected to indicate a greater number of arsenic detections than would be found through random sampling. The results from those programs, therefore, are not considered representative of ground-water quality throughout Suffolk County.

The areal distribution of elevated concentrations detected during 1997 through 2001 and 2002 does not indicate a strong correlation with agricultural land use, contrary to expectation. This is consistent with a conclusion reported by SCDHS that very few of the low-level detections of arsenic can be attributed to the leaching of pesticides (NYSDEC web page-http://www.dec.state.ny.us/website/dshm/prl/scdhs1c. htm; accessed 06/12/02).

\section{References Cited}

Bradley, C.B., Minei, Vito, and Trent, Martin, 2000, Water quality monitoring program to detect pesticide contamination in groundwaters of Nassau and Suffolk Counties, NY - annual report for the water quality monitoring program, April 1999 through March 2000: Suffolk County Department of Health Services, Division of Environmental Quality and Bureau of Groundwater Resources, $39 \mathrm{p}$.

Bradley, C.B., Minei, Vito, Trent, Martin, and Robbins, S.F., 2002, Water quality monitoring program to detect pesticides in groundwaters of Nassau and Suffolk Counties, NY - monitoring conducted April 2000-March 2001: Suffolk County Department of Health Services, Division of Environmental Quality and Bureau of Groundwater Resources, May 2002, 68 p.

Brown, C.J. and Chute, S.K., 2002, Arsenic concentrations in bedrock wells in Colchester, East Hampton, and Woodstock, Connecticut: U.S. Geological Survey WaterResources Investigations Report 02-4135, 23 p.

Jones, S.R., and Garbarino, J.R., 1999, Methods of analysis by the U.S. Geological Survey National Water Quality Laboratory-Determination of arsenic and selenium in water and sediment by graphite furnace-atomic absorption spectrometry: U.S. Geological Survey Open-File Report 98-639, 39 p.

McClymonds, N.E., and Franke, O.L., 1972, Watertransmitting properties of aquifers on Long Island, New York: U.S. Geological Survey Professional Paper 627-E, $24 \mathrm{p}$. 
National Research Council, 1999, Arsenic in drinking water: Washington, DC., National Academy Press, 273 p.

New York State Department of Environmental Conservation, 1999, Water quality monitoring program to detect pesticides in groundwater of Nassau and Suffolk Counties, N.Y., final report: June 1999. (Website: http://www.dec.state.ny.us/ website/dshm/prl/scdhslc.htm, accessed 6/12/02.)

Nickson, Ross, McArthur, John, Burgess, William, and others, 1998, Arsenic poisoning of Bangladesh groundwater: Nature, v. 395, p. 338.

Pluhowski, E.J., and Kantrowitz, I.H., 1964, Hydrology of the Babylon-Islip area, Suffolk County, Long Island, N.Y.: U.S. Geological Survey Water-Supply Paper 1768, 119 p.

Sanok, W.J., Ebel, J.G., Jr., and Manzell, K.L., 1995, Residues of arsenic and lead in potato soils on Long Island: Chemosphere, v. 30, no. 4, p. 803-806.
Smolensky, D.A., Buxton, H.T., and Shernoff, P.K., 1989, Hydrologic framework of Long Island, New York: U.S. Geological Survey Hydrologic Investigations Atlas HA709, 3 sheets, scale 1:250,000.

U.S. Environmental Protection Agency, 2001a, Drinking water standard for arsenic: USEPA Technical Fact Sheet 815-F00-015, 3 p.

U.S. Environmental Protection Agency, 2001b, Final rule for arsenic in drinking water: USEPA Technical Fact Sheet 815-F-00-016, 6 p.

Welch, A.H., Watkins, S.A., Helsel, D.R., and Focazio, M.J., 2000, Arsenic in ground-water resources of the United States: U.S. Geological Survey Fact Sheet 063-00, May 2000, 12 p. 